\title{
LS2-4 症例に学乃゙脳腫瘍病理
}

\section{1. 良性腫煬：3 症例}

\section{【症例 1】}

京都大学医学部脳神経外科 ${ }^{1}$

京都大学医学部中検病理部 2

高橋 $\quad$ 潤 $^{1}$ 北条雅 人 $^{1}$ 橋本信 $夫^{1} \quad$ 中嶋安彬 ${ }^{2}$

\section{患 者: 7 歳, 女児}

元来精神発達遅延を呈していた，養護学校入学後，低身長の精查により，沉下垂体機能低下症，仮面尿崩症を指摘さ れ，画像診断にて鞍内から鞍上部に石灰化を伴う囊胞性腫瘍を認めた。

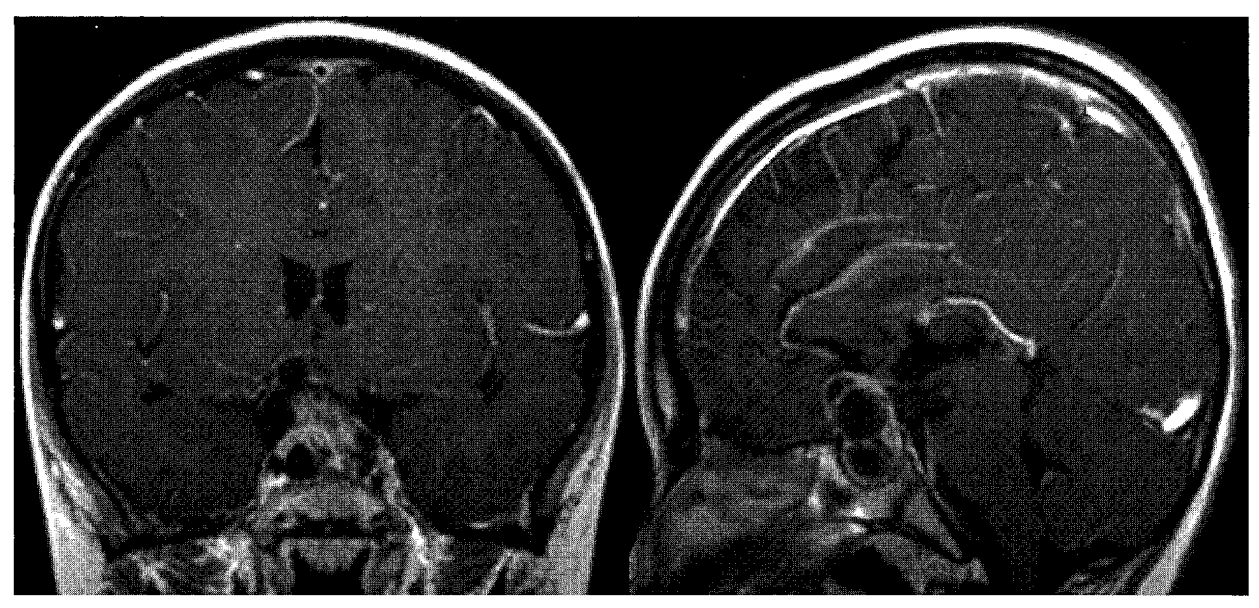

\section{【症例 2】}

\section{患 者: 22 歳, 女性}

頭痛を自覚し，蝶形骨洞から周囲に浸潤する腫隆性病変を認めた。左外転神経麻痺，視野視力障害が進行してきたた め，他院にて手術を試みたが，出血により減厓も困難であった．放射線治療が行われたが，視機能障害は進行し，転院 時には左手動弁となっていた。

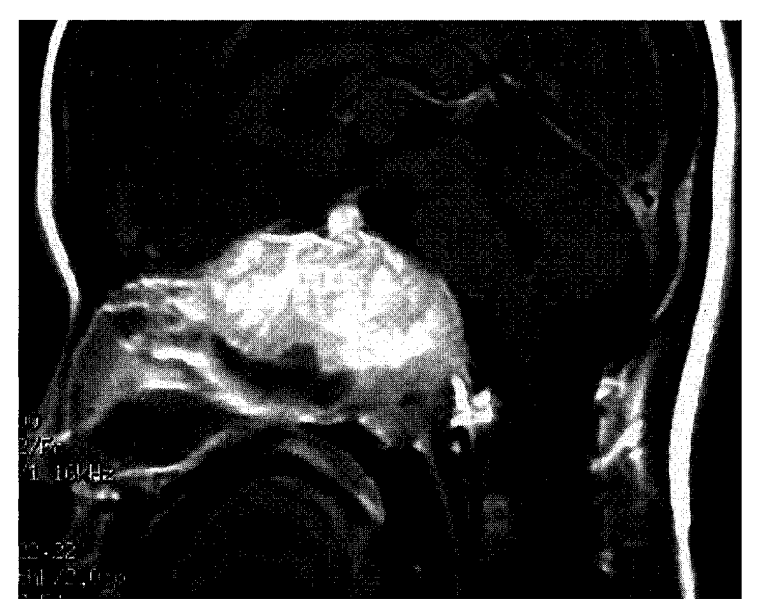




\section{【症例 3】}

\section{患 者: 53 歳，女性}

35 歳時に他院で下垂体部腫瘍を摘出, 頭蓋咽頭腫と診断された４４歳時に再増大し，摘出した結果，ラトケ囊胞と 診断された。 その後, 50 歳時, 52 歳時, 53 歳時に再増大したため, 最終手術の術後放射線照射を試みた. その後 2 年 再発なく経過している.

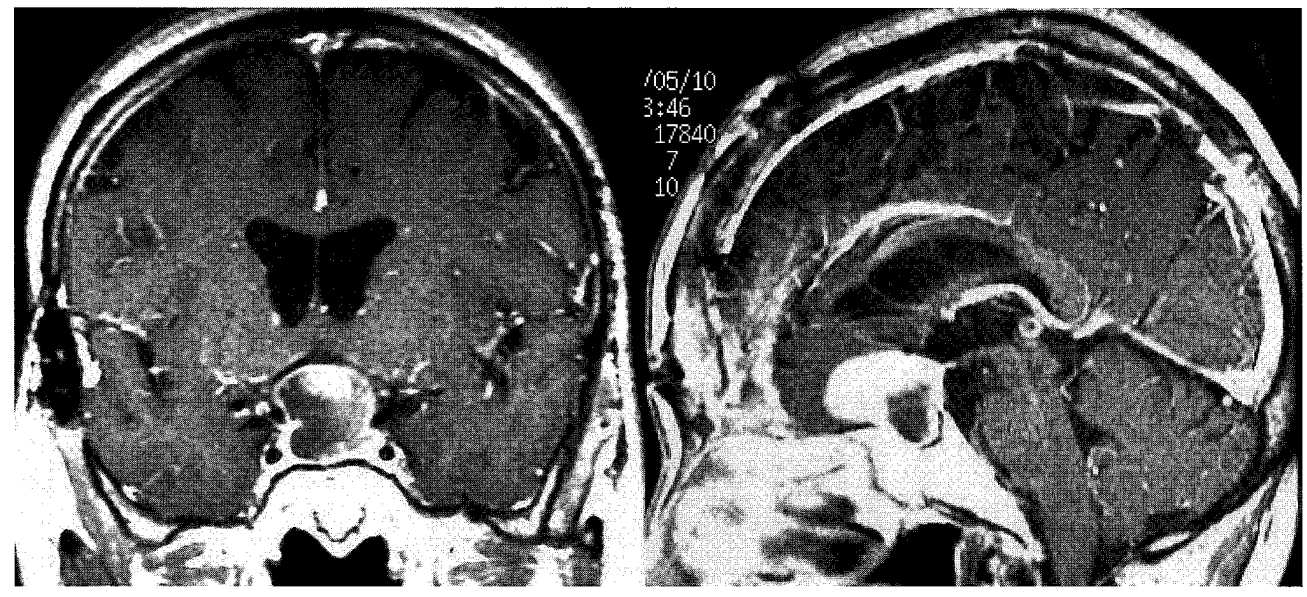

\section{2.グリオーマ: 3 症例}

香川大学医学部脳神経外科 田宮隆

\section{【症例 1】}

患 者: 1 歳, 女児

主 訴: 䓵吐, 発熱

家族歴・既往歴：特記すべきことなし

現病歴： 1 週間ほど前に嘔吐が認められ，近医を受診し経過をみていた. 39 度の発熱が認められ，当院小児科受診し， 頭部 CT にて右小脳半球に囊胞性病変と一部出血を伴った部位が認められたため入院となった.

入院時所見：意識レベルは清明で，特に四肢麻痺など認めず，元気であった。

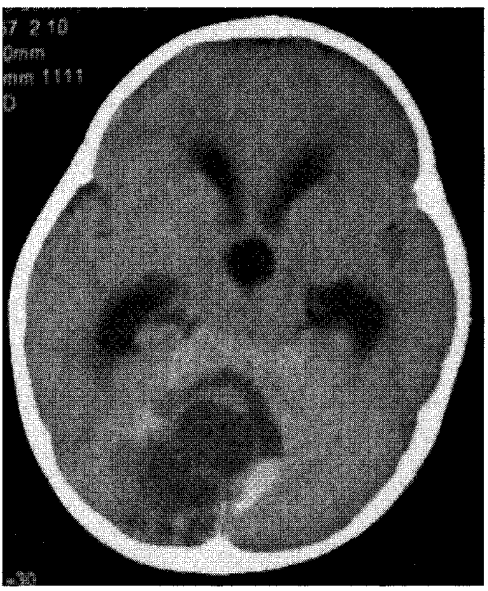

CT

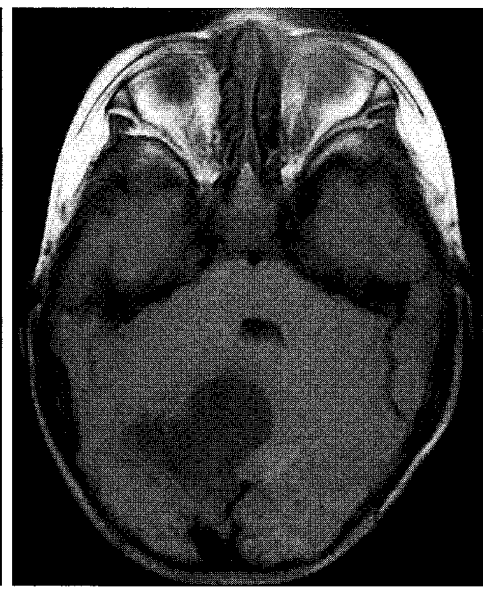

T1WI

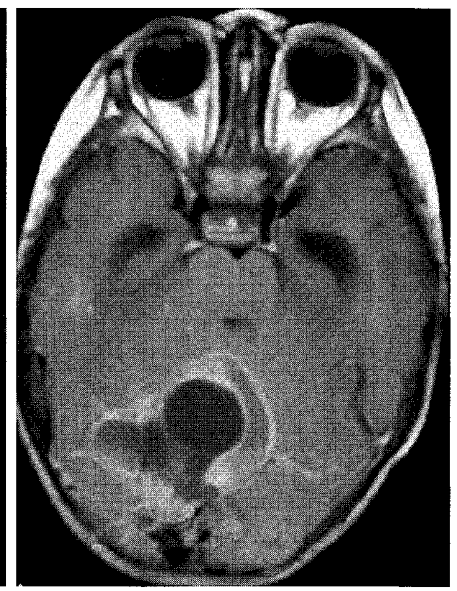

Gd 